\title{
ERß1 represses basal-like breast cancer epithelial to mesenchymal transition by destabilizing EGFR
}

\author{
Christoforos Thomas ${ }^{1 *}$, Gayani Rajapaksa ${ }^{1 \dagger}$, Fotis Nikolos ${ }^{1 \dagger}$, Ruixin Hao ${ }^{1}$, Anne Katchy ${ }^{1}$, Catherine W McCollum', \\ Maria Bondesson ${ }^{1}$, Phil Quinlan², Alastair Thompson², Savitri Krishnamurthy ${ }^{3}$, Francisco J Esteva ${ }^{4}$ and \\ Jan-Åke Gustafsson ${ }^{1}$
}

\begin{abstract}
Introduction: Epithelial to mesenchymal transition (EMT) is associated with the basal-like breast cancer phenotypes. Sixty percent of basal-like cancers have been shown to express wild-type estrogen receptor beta (ER $\beta 1)$. However, it is still unclear whether the ER $\beta$ expression is related to EMT, invasion and metastasis in breast cancer. In the present study, we examined whether ER $\beta 1$ through regulating EMT can influence invasion and metastasis in basal-like cancers.

Methods: Basal-like breast cancer cells (MDA-MB-231 and Hs578T), in which ERß1 was either overexpressed or down-regulated were analyzed for their ability to migrate and invade (wound-healing assay, matrigel-coated Transwell assay) as well as for the expression of EMT markers and components of the EGFR pathway (immunoblotting, RT-PCR). Co-immunoprecipitation and ubiquitylation assays were employed to examine whether ER $\beta 1$ alters epidermal growth factor receptor (EGFR) protein degradation and the interaction between EGFR and the ubiquitin ligase c-Cbl. The metastatic potential of the ER $\beta 1$-expressing MDA-MB-231 cells was evaluated in vivo in a zebrafish xenotransplantation model and the correlation between ER $\beta 1$ and E-cadherin expression was examined in 208 clinical breast cancer specimens by immunohistochemistry.
\end{abstract}

Results: Here we show that ERß1 inhibits EMT and invasion in basal-like breast cancer cells when they grow either in vitro or in vivo in zebrafish. The inhibition of EMT correlates with an ERß1-mediated up-regulation of miR-200a/b/ 429 and the subsequent repression of ZEB1 and SIP1, which results in increased expression of E-cadherin. The positive correlation of ER $\beta 1$ and E-cadherin expression was additionally observed in breast tumor samples. Downregulation of the basal marker EGFR through stabilization of the ubiquitin ligase c-Cbl complexes and subsequent ubiquitylation and degradation of the activated receptor is involved in the ERß1-mediated repression of EMT and induction of EGFR signaling abolished the ability of ERß1 to sustain the epithelial phenotype.

Conclusions: Taken together, the results of our study strengthen the association of ER $\beta 1$ with the regulation of EMT and propose the receptor as a potential crucial marker in predicting metastasis in breast cancer.

\section{Introduction}

In the last decade, genomic studies have identified five breast cancer intrinsic subtypes (Luminal A, Luminal B, HER2 (overexpressing the ERBB2), basal-like and claudin-low) [1,2]. In a recent study, an integrated analysis of copy number and gene expression split the intrinsic

\footnotetext{
* Correspondence: chthomas@uh.edu

† Contributed equally

'Department of Biology and Biochemistry, Center for Nuclear Receptors and Cell Signaling, University of Houston, 3605 Cullen Blvd., Houston, TX 77204, USA

Full list of author information is available at the end of the article
}

subtypes revealing novel subgroups with distinct clinical outcome, including a high-risk ER $\alpha$-positive subgroup and a subset of $E R \alpha$-positive and ER $\alpha$-negative cases with a favorable outcome. According to this analysis, the majority of the basal-like tumors formed a highgenomic instability subgroup with relatively good longterm outcomes (after five years) [3]. Basal-like phenotypes represent tumors that express markers that are characteristic of the myoepithelium of the normal mammary gland, such as epidermal growth factor receptor (EGFR), p63 and the basal cytokeratins CK14, CK5/6

\section{Biomed Central}


and CK17 [1,4]. They show partial overlap with the triple-negative breast cancers that are characterized by a lack of HER2 gene amplification and estrogen and progesterone receptor expression. Approximately $75 \%$ of triple-negative breast cancers are classified as basal-like tumors on the basis of their overall gene-expression profile. The basal-like phenotype represents a more homogeneous group of cancers than the group of cancers defined by triple negativity [5]. Basal-like tumors are often resistant to chemotherapy and develop distant metastases in characteristic tissues, such as lung and brain [6]. Recent studies have suggested a correlation between the basal phenotypes and epithelial to mesenchymal transition (EMT) [7].

EMT has been reported to promote invasion during the progression of breast carcinomas and it is considered as an essential early step in tumor metastasis [8,9]. EMT is characterized by loss of cellular adhesion, which is mediated by down-regulation of adhesion molecules, such as CD44 and E-cadherin $[10,11]$. The expression of E-cadherin is regulated by a number of transcriptional repressors, which include SNAIL, SLUG, SIP-1 (ZEB-2), $\delta$ EF1 (ZEB-1) and TWIST [12-15]. The family of microRNAs 200 (miR-200a, miR-200b, miR-200c, miR-141 and miR-429) and the miR-205A regulate the expression of the transcriptional repressors of E-cadherin ZEB-1 and ZEB-2 and, consequently, the levels of E-cadherin in breast cancer cells and tissues. A decrease in the expression of these microRNAs has been observed in cells that have undergone EMT and in mesenchymal regions of metaplastic breast cancer lacking E-cadherin expression [16]. Up-regulation of components of the EGFR signaling pathway, such as ERK2, has also been reported to influence the levels of E-cadherin by regulating the transcriptional repressors ZEB-1 and ZEB-2 [17,18].

The potential role of estrogen receptors in regulating EMT and aggressive behavior in breast cancer has recently been under investigation [19]. Although a decline of ER $\alpha$ levels is detected in invasive breast cancers, a few studies have shown regulation of cell migration and invasion by $E R \alpha[20,21]$. Recent studies have also associated the ER $\beta$ isoforms ER $\beta 1, E R \beta 2$ and ER $\beta 5$ with the regulation of cell migration and invasion in prostate cancer [22,23]. Downregulation of the fully functional ER $\beta$ isoform ER $\beta 1$ (also known as wild-type ER $\beta$ ) promoted EMT in prostate cancer cells and this correlated with the loss of ER $\beta 1$ in high Gleason grade invasive prostate carcinoma [22]. Interestingly, patients with triple-negative breast cancer that were treated with adjuvant tamoxifen have been shown to have significantly better survival when the tumors were positive for ER $\beta 1$ [24]. In addition, clinical findings showed an inverse correlation between ER $\beta 1$ positivity and expression of EGFR, a crucial component in basal-like cancers that drives proliferation and EMT [25]. Given that down-regulation of ER $\beta 1$ has been observed in invasive breast cancers, in this study we hypothesized that ER $\beta 1$ functions to maintain an epithelial phenotype in breast cancer and examined whether ER $\beta 1$ reduces the invasiveness of basal cancer cells by repressing EMT [26].

\section{Materials and methods}

\section{Cells, reagents and transfections}

The breast cancer cell lines (MDA-MB-231, Hs578T and MCF-7) and the lung cancer cell line (H1299) were obtained from the ATCC. In 17ß-estradiol (E2) experiments, cells were maintained in phenol red-free media containing two or five percent dextran-coated charcoal (DCC)treated fetal calf serum (FCS). Transforming growth factor $\beta$ (TGF- $\beta$ ) and EGF experiments were performed in serum-free or $0.5 \%$ FCS media with recombinant human TGF- $\beta 1$ ( $5 \mathrm{ng} / \mathrm{ml}$; R \& D Systems, Minneapolis, MN USA) for one to three days or EGF (10 ng/ml; Sigma) for $24 \mathrm{~h}$. MDA-MB-231 and Hs578T cells were infected with lentiviruses containing the plenti6/V5 empty vector or the recombinant pLenti6/V5-D-FLAG-ER $\beta 1$ and pLenti6/V5D-FLAG-ER $\alpha$ plasmids as described previously [27]. Cells were transfected twice with ER $\beta$-specific siRNAs (Invitrogen, Carlsbad, CA USA), target sequences 1\# 5'-TTAGCGACGTCTGTCGCGTCTTCAC-3'; 2\# 5'-TTACGAC ATTAAGTAGTGTCGTCCC-3'; 3\# 5'-TATTGACCGCTACCTGGTGATTTCC-3'. siRNA targeting luciferase was used as a control (Cat. No. 12935-146, Invitrogen). For the expression of wild-type EGFR, cells were stably transfected with the pBABE-EGFR construct (Addgene, plasmid \# 11011, Cambridge, MA USA), using the empty pBABE vector (Addgene, plasmid \# 1764) as a control. Cells were transfected with microRNA inhibitors at a final concentration of $300 \mathrm{nM}$ (100 nM of each of miR-200a, miR-200b and miR-429 2'-O-Methylmodified oligonucleotides, Dharmacon, Waltham, MA USA) or a negative control inhibitor $(300 \mathrm{nM})$. The complementary sequences for miR-200a, miR-200b and miR-429 were cloned in the 3 ' end of the luciferace gene into the PGL3-promoter vector (Promega, San Luis Obispo, CA USA). A total of $2 \times 10^{5}$ cells were seeded at 24-well plates and transfected with 800 ng DNA/ well (PGL3, $\beta$-gal) as well as microRNA inhibitors. Twenty-four hours after transfection, cells were lysed and analyzed using a Luciferase Assay (Promega). Luciferase units were normalized to $\beta$-galactosidase units. For EREluciferase reporter assays, cells were incubated in DCCFCS media for $48 \mathrm{~h}$ and transfected with $800 \mathrm{ng}$ DNA/well (3-ERE-TATA-LUC reporter plasmid, $\beta$-gal plasmid) using LipofectamineTM 2000 (Invitrogen). Cells were mock treated (EtOH) or treated with E2 for $24 \mathrm{~h}$ in 2\% DCC-FCS media. Reporter gene activity was normalized to $\beta$-galactosidase enzyme activity. 


\section{Migration and invasion assays}

In the wound-healing assay, cells were allowed to form monolayers at 24-well plates. The monolayer was scratched with a pipette tip to form the wound. Twelve hours later, images of the wound were taken using a 10x objective in an OLYMPUS IX51 microscope equipped with an OLYMPUS camera (OLYMPUS, Center Valley, PA USA) and cells in the wound area in five independent fields were counted.

In the invasion assay, cells were seeded in matrigelcoated $6.5 \mathrm{~mm}$ Transwell champers $(8 \mu \mathrm{m}$ pore size; BD Biosciences, San Jose, CA USA). Six hours later, the cells that had been translocated to lower compartments of the wells and attached to the lower surface of the filter were fixed in methanol and stained with crystalviolet. The stained cells were counted in five independent fields in each Transwell.

\section{Immunofluorescence and microscopy}

Cells were plated onto $18 \mathrm{~mm}^{2}$ coverslips, fixed in $3 \%$ paraformaldehyde (PFA) and $2 \%$ sucrose for 15 minutes at room temperature (RT), permeabilized in $20 \mathrm{mM}$ Tris $\mathrm{HCI} \mathrm{pH} 7.5,75 \mathrm{mM} \mathrm{NaCl}, 300 \mathrm{mM}$ sucrose, $3 \mathrm{mM} \mathrm{MgCl} 2$ and $0.5 \%$ Triton-X-100 for 15 minutes at RT and blocked with $5 \%$ goat serum in phosphate-buffered saline (PBS) for $1 \mathrm{~h}$ at RT. Slides were stained with an E-cadherin antibody (BD Biosciences) at $4^{\circ} \mathrm{C}$ overnight, washed, incubated with secondary antibody and images were collected on an OLYMPUS BX51 microscope equipped with an OLYMPUS XM10 camera (OLYMPUS, Center Valley, PA USA).

\section{RNA extraction and real-time PCR}

Total RNA was isolated using TriZol reagent (Invitrogen) and reverse-transcribed to cDNA using a SuperScript ${ }^{\mathrm{TM}}$ II reverse transcriptase kit (Invitrogen). Real-Time PCR was performed using the SyBr green PCR kit (Applied Biosystems, Grand Island, NY USA). EGFR mRNA levels were additionally analyzed using TaqMan mRNA assay according to the manufacturer's instructions (Applied Biosystems). All quantitative data were normalized to GAPDH and actin- $\beta$. For microRNAs, real-time PCR was performed as above using TaqMan microRNA assays (Applied Biosystems). All microRNA data are expressed relative to a U6 small nuclear (sn) RNA TaqMan PCR performed on the same sample. The sequences of the primers used for qPCR are listed in the Additional file 1, Table S1.

\section{Immunoblotting and immunoprecipitation}

Cells were lysed in RIPA buffer, including protease and phosphatase inhibitors as previously described [28]. For separation of cytoplasmic and nuclear fractions, cells were suspended in a cold buffer containing $10 \mathrm{mM}$ Hepes pH 7.0, 10 mM KCI, 0.1 mM EDTA, 1 mM DTT and $0.5 \mathrm{mM}$ PMSF. After 15 minutes' incubation on ice, the homogenate was mixed with $10 \% \mathrm{NP}-40$ and centrifuged for $30 \mathrm{sec}$. The nuclear pellet was resuspended in a cold buffer containing $10 \mathrm{mM}$ Hepes- $\mathrm{KOH}$ pH 7.9, $400 \mathrm{mM} \mathrm{NaCI}, 0.1 \mathrm{mM}$ EDTA, 5\% glycerol, $1 \mathrm{mM}$ DTT and $0.5 \mathrm{mM}$ PMSF and the nuclear extract was isolated by centrifugation. The blots were performed as previously described [28]. Primary antibodies used in immunoblotting include: $\mathrm{ER} \alpha, \mathrm{E}$-cadherin, N-cadherin, cadherin-11, vimentin, ZEB-1, SIP1, Lamin A/C and Tubulin (Santa Cruz Biotechnology, Santa Cruz, CA USA), actin- $\beta$ (Sigma St. Louis, MO USA), EGFR (Santa Cruz Biotechnology, Cell Signaling, Danvers, MA USA), ER $\beta 1$ (14C8; GeneTex, Irvine, CA USA), which detects an N-terminal epitope and recognizes the ER $\beta$ isoforms derived from alternative splicing of the last exon, including ER $\beta 1$ and an in-house antibody that detects an epitope in ligand binding domain of ER $\beta 1$ (amino acids 320 to 527)) [29], SNAIL (Abcam, Cambridge, MA USA), p-ERK1/2 and total ERK1/2 (Cell Signaling), c-Cbl (BD Biosciences). Recombinant ER $\beta 1$ (Invitrogen) was loaded in SDSPAGE gels and used as a positive control. For ubiquitylation analysis, cells were lysed in RIPA buffer containing protease inhibitor cocktail (Roche, Branchburg, NJ USA). The lysates were briefly sonicated and cleared by centrifugation at $4{ }^{\circ} \mathrm{C}$. Supernatants were incubated with antiEGFR antibody overnight at $4^{\circ} \mathrm{C}$ and $\mathrm{A} / \mathrm{G}$ agarose beads for $2 \mathrm{~h}$ at $4^{\circ} \mathrm{C}$. The immunocomplexes were washed three times, boiled in $2 \times$ sample buffer and immunoblotted with anti-ubiquitin antibody (Santa Cruz Biotechnology). For the EGFR-c-Cbl co-immunoprecipitations, cells were lysed in a buffer containing $50 \mathrm{mM}$ Hepes $\mathrm{pH} 7.4,150 \mathrm{mM}$ $\mathrm{NaCI}, 1 \mathrm{mM}$ EDTA, 1 mM EGTA, 1\% Nonidet P-40, 1\% glycerol including protease and phosphatase inhibitors. Lysates were incubated on ice for 30 minutes without sonication, cleared by centrifugation and the cleared lysates were subjected to immunoprecipitation as described.

\section{Zebrafish tumor model and generation of fluorescent cells}

Animal work was approved by the Institutional Animal Care and Use Committee (IACUC) at the University of Houston. Control (Lenti) and ER $\beta 1$-expressing (ER $\beta 1$ ) MDA-MB-231 cells were stably transfected with either the pAmCyan vector or the pCMCV-DsRed vector (Clontech, Mountain View, CA USA). A tumor cell suspension ( $5 \mathrm{~nL}$ ) of approximately 300 to 500 cells containing a mixture of equal numbers of either DsRed-Lenti: AmCyan-ER $\beta 1$ cells or AmCyan-Lenti:DsRed-ER $\beta 1$ cells were injected into the perivitelline cavity of each $48 \mathrm{~h}$ post-fertilization casper $T g(F l k-1 ; E G F P)$ anesthetized embryo using a pressure injector (Harvard Apparatus, Holliston, MA USA) and Manipulator (MM33-Right, Märzhäuser Wetzlar, Wetzlar, Germany). Glass needles $(1.00 \mathrm{~mm}$ in diameter, Sutter Instrument Company, 
Novato, CA USA), were used for the microinjection. Injected embryos were kept at $32^{\circ} \mathrm{C}$ and were examined every day for tumor invasion using a fluorescent microscope (OLYMPUS IX51) equipped with an OLYMPUS XM10 camera. Information for the zebrafish lines is included in the Additional file 2, Supplementary materials and methods.

\section{Patient information}

A tissue microarray consisting of 240 breast cancer samples was constructed by the Tayside Tissue Bank. Access to tumor samples was approved by the Tayside Regional Ethics Committee with written informed consent from contributing patients. Clinical history and tumor characteristics were available for 238 cases. The clinicopathological characteristics of these patients are summarized in the Additional file 3, Table S2. The majority of the patients received adjuvant endocrine therapy or combined endocrine therapy and chemotherapy, with or without radiotherapy. Among these patients, $74.7 \%$ were ER $\alpha$-positive, 53.7\% were PR-positive and $14.5 \%$ were HER2-positive. Histologically, 192 invasive ductal carcinomas (80.6\%), 14 invasive lobular carcinomas (5.8\%), 5 tubular carcinomas (2.1\%), 5 mucinous carcinomas (2.1\%) and 22 other histological or mixed types $(9.2 \%)$ were included.

\section{Antibody validation and immunohistochemistry}

The anti-ER $\beta 1$ antibody (clone PPG5/10, Dako, Carpinteria, CA USA), which is specific for the C-terminal amino acid sequences of ER $\beta 1$, was used for immunohistochemistry (IHC). This antibody was validated by immunocytochemistry. Briefly, H1299 human lung cancer cells were stably transfected with the pIRES empty vector (Clontech) or the recombinant pIRES-ER $\beta 1$ or pIRES-ER $\beta 2$ plasmids. Control, ER $\beta 1$ and ER $\beta 2$-expressing cells were fixed with $10 \%$ formalin. The cell suspension was centrifuged and the cell pellet was folded in sharkskin filter paper using four overlapping edges and placed within the base of a tissue cassette. The cassette was placed in a specimen bucket with $10 \%$ formalin. The formalin-fixed cell material was embedded in paraffin, cut at $5 \mu \mathrm{m}$ intervals and used for H\&E staining and IHC.

For immunohistochemistry, formalin-fixed, paraffinembedded sections were de-paraffinized with xylene and rehydrated through a graded alcohol series. For antigen retrieval, the slides were immersed in $10 \mathrm{mM}$ sodium citrate buffer ( $\mathrm{pH} \mathrm{6.0)}$ and maintained at a sub-boiling temperature for six minutes. The endogenous peroxidase activity was blocked by incubation in $0.3 \%$ hydrogen peroxide solution for 20 minutes. The slides were first incubated with $1 \%$ bovine serum albumin (BSA) to block non-specific staining and then with the primary antibody overnight at $4^{\circ} \mathrm{C}$ in a humidified chamber. The sections were then processed according to the Dako DAB detection kit.
The results of the immunohistochemistry were assessed by a pathologist (SK) in a blinded fashion. Each specimen was assigned a score according to the intensity of the nuclear staining (for ER $\beta 1$ ) and cytoplasmic and membrane staining (for E-cadherin) (no staining $=0$, weak staining $=1$, moderate staining $=2$, strong staining $=3$ ) and the extent of stained cells $(0 \%=0,1$ to $24 \%=1,25$ to $49 \%=2,50$ to $74 \%=3,75$ to $100 \%=4)$. The final immunoreactive score was determined by multiplying the intensity score with the extent of the score of stained cells, ranging from 0 (the minimum score) to 12 (the maximum score). We defined ER $\beta 1$ expression as low (score 0 to 4), medium (score 5 to 8 ) and high (score 9 to 12). For E-cadherin, we defined a 0 score as negative and a 1 to 12 as positive.

\section{Statistical analysis}

The correlation between expression of ER $\beta 1$ and E-cadherin, respectively, was determined using Pearson's correlation test. All statistical tests were two-sided and $P$-values less than or equal to 0.05 were considered as statistically significant. The statistical analyses were performed using SPSS 20.0 software (SPSS, IBM, Armonk, NY USA).

\section{Results}

\section{ER $\beta 1$ is required for the epithelial breast cancer phenotype}

Basal-like phenotypes are high-grade (grade III), ER $\alpha$ negative invasive breast tumors that express EMT markers and show cadherin switching as a consequence of tumor de-differentiation [7]. Previous studies have shown a decline of ER $\beta 1$ expression from ductal carcinoma in situ (DCIS) to invasive cancer and an association of the receptor with the repression of mesenchymal characteristics in invasive prostate cancer [22,30,31]. We hypothesized that ER $\beta 1$ regulates EMT in breast cancer and that low ER $\beta 1$ expression in a proportion of basal-like cancers is associated with mesenchymal characteristics and poor clinical outcome. To test this hypothesis, we stably expressed ER $\beta 1$ in the invasive triple-negative breast cancer MDAMB-231 and Hs578T cells and compared the expression levels achieved in these cells with the endogenous expression of ERs in MCF-7 cells (Additional file 4, Figure S1). According to recent studies, MDA-MB-231 and Hs578T cells most resemble the claudin-low breast cancer subtype; however, as basal-like tumors, they display low expression of the luminal and HER2 gene clusters and express low amounts of ER $\beta 1$ [32]. Induction of ER $\beta 1$ expression promoted morphological changes in these cells characterized by the loss of the "fibroblastoid-like" phenotype and the acquisition of an epithelial-like compact morphology (Figure 1A, B, upper panel). Furthermore, a more spindleshaped morphology was observed when endogenous ER $\beta 1$ was knocked down with ER $\beta$ siRNA in Hs578T cells 

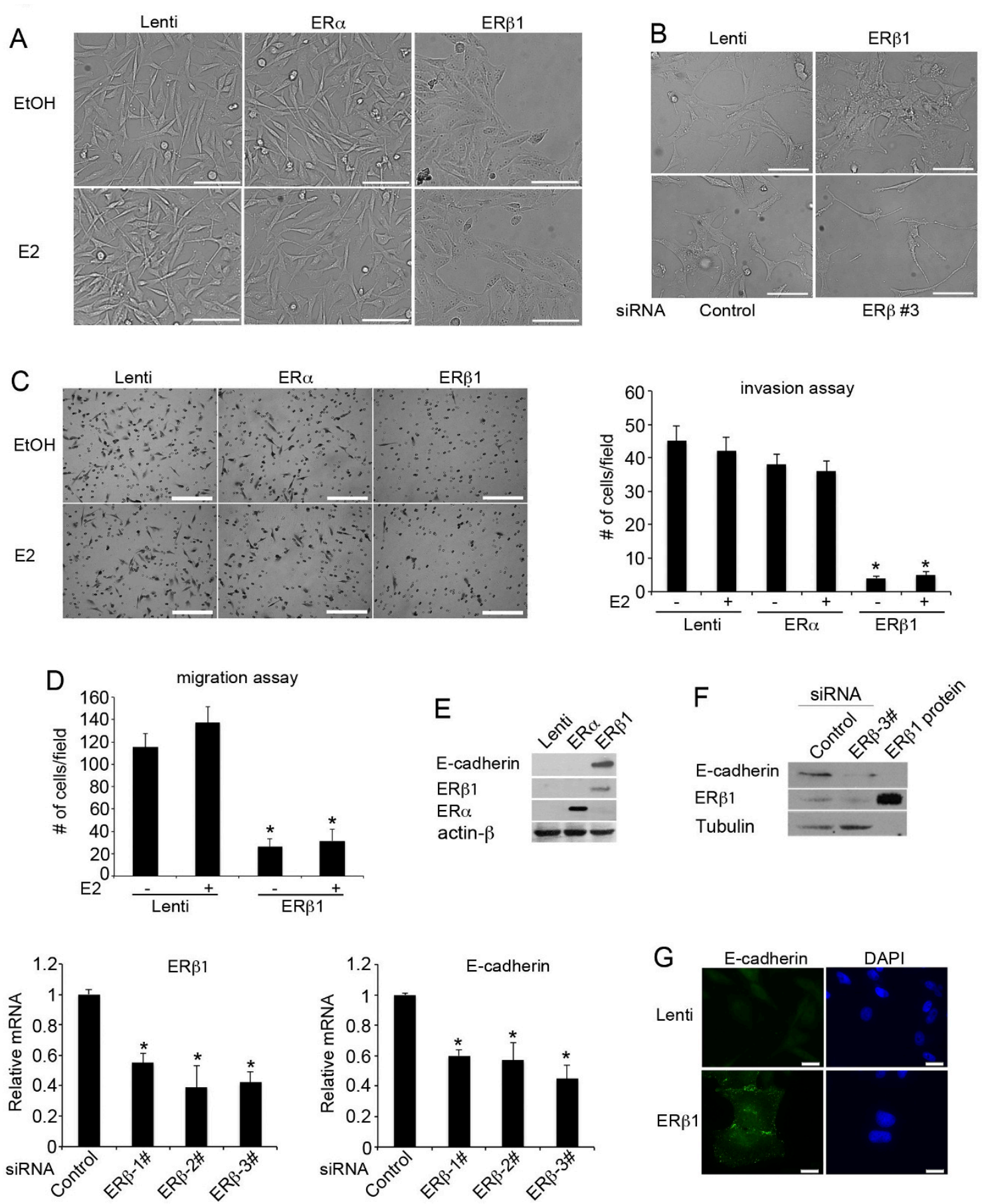

Figure 1 ER $\beta 1$ inhibits invasion and migration in breast cancer cells by regulating EMT. (A) Control (Lenti), ER $\alpha$ - and ER 1 -expressing MDA-MB-231 cells following incubation with EtOH or 17ß-estradiol (E2) for $24 \mathrm{~h}$ (scale bars, $50 \mu \mathrm{m}$ ). (B) Control (Lenti) and ERß 1-expressing Hs578T cells (upper panel) and Hs578T cells that were transiently transfected with a siRNA targeting luciferase (Control) or a specific ER $\beta$ siRNA (siRNA 3\#) (lower panel) were photographed (scale bars, 100 MM). (C) Control (Lenti), ER $\alpha$ - and ER $\beta 1$-expressing MDA-MB-231 cells were incubated with EtOH or E2 and assessed for invasion by using matrigel-coated Transwell chambers. The cells that were translocated to the lower surface of the filter were shown (left panel) (scale bars, $500 \mu \mathrm{m}$ ). The graph shows the mean (cell number per field) of three separate experiments with the standard error of the mean (SEM) and $P$-value $\left(^{*}\right) \leq 0.05 \%$ indicated. (D) Control (Lenti) and ER $\beta 1$-expressing MDA-MB-231 cells were incubated with E2 for $24 \mathrm{~h}$ and assessed for migration using wound-healing assay. The bar graph shows the mean (cells migrated into the wound) of three separate experiments with SEM and P-value $\left(^{*}\right) \leq 0.05 \%$ indicated. (E) E-cadherin protein levels in control (Lenti), ER $\alpha$ or ERß1-expressing MDA-MB-231 cells. (F) E-cadherin expression was analyzed by immunoblotting in MDA-MB-231 cells transfected with control or ERß siRNA (3\#) (upper panel) and GPCR in MDA-MB-231 cells transfected with control or three specific ERß siRNAs (lower panel). The graph indicates the mean of three separate experiments with SEM and $P$-value $\left(^{*}\right) \leq 0.05 \%$. (G) E-cadherin was visualized by immunofluorescence in control (Lenti) and ERß1-expressing cells (scale bars, $20 \mu \mathrm{m}$ ). 
(Figure 1B, lower panel). Induction of ER $\beta 1$ expression altered the morphology of the MDA-MB-231 and Hs578T cells in the absence of ligand. The morphology of the ER $\beta 1$-expressing MDA-MB-231 cells following treatment with $17 \beta$-estradiol (E2) was similar to that of the untreated cells (Figure 1A). Consistent with the changes in the morphology, induction of ER $\beta 1$ expression in MDA-MB-231 cells repressed invasion and migration (Figure 1C, D), functions characteristic of EMT [33]. Although induction of ER $\beta 1$ and ER $\alpha$ expression resulted in a similar activation of an ERE-luciferase reporter, ER $\alpha$ failed to promote epithelial morphology and reduce the invasiveness of MDA-MB-231 cells (Figure 1A, C; Additional file 4, Figure S1; Additional file 5, Supplementary figure legends). Similar to the impact on the cellular morphology and invasiveness, only ER $\beta 1$ inhibited cadherin switching as shown by the up-regulation of epithelial E-cadherin in both MDA-MB-231 and Hs578T cells and down-regulation of the mesenchymal cadherin-11 in MDA-MB-231 and $\mathrm{N}$-cadherin in Hs578T cells (Figures $1 \mathrm{E}$ and 2A, B; Additional file 6 Figure S2A). The positive correlation between ER $\beta 1$ and E-cadherin expression was confirmed by the decrease of E-cadherin mRNA and protein levels when ER $\beta 1$ was knocked down in MDA-MB-231 cells (Figure 1F). In line with the results from the immunoblotting analysis, immunofluorescence showed higher expression of E-cadherin in the cell surface of the ER $\beta 1$ expressing cells compared to the control cells (Figure 1G). This suggests that ER $\beta 1$ up-regulates the functional form of E-cadherin that promotes cell-cell adhesion. No alteration in the levels of the mesenchymal marker vimentin was detected in ER $\beta 1$-expressing MDA-MB-231 cells suggesting that ER $\beta 1$ induces cell-cell adhesion in these cells by primarily regulating the expression of cadherin (Figure 2B; Additional file 6 Figure S2B).

\section{miR-200 and ZEB1/2 are involved in ERß1-mediated regulation of E-cadherin}

A number of transcription factors (SNAIL, SLUG, TWIST, SIP-1 and ZEB-1) have been shown to promote EMT in vitro by acting as transcriptional repressors of E-cadherin $[34,35]$. Nuclear translocation of SNAIL has been shown to repress E-cadherin expression in ER $\beta 1$ knockdown prostate cancer cells [22]. Based on these data, we examined whether SNAIL inhibition is involved in the ER $\beta 1$ mediated induction of E-cadherin expression that we observed in breast cancer cells. Surprisingly, induction of ER $\beta 1$ expression in MDA-MB-231 cells neither altered the expression nor the intracellular localization of SNAIL as assessed by immunoblotting using cytoplasmic and nuclear extracts from control and ER $\beta 1$-expressing cells as well as immunofluorescence microscopy using a SNAIL Ab (Additional file 7, Figure S3A, B). Instead, up-regulation of ER $\beta 1$ in MDA-MB-231 and Hs578T cells repressed the expression of the transcriptional repressors of E-cadherin ZEB-1 and SIP-1 (Figure 2C). Given that recent studies have reported that the microRNA-200 family and miR-205 regulate EMT by targeting ZEB-1 and SIP-1, we examined whether the expression of members of the microRNA-200 family and miR-205 were up-regulated prior to repression of ZEB- 1 and SIP-1 expression in ER $\beta 1$-expressing cells [16]. Using quantitative real-time PCR we found that the cluster of miR-200b-200a-429 was up-regulated by more than 7 -fold in the ER $\beta 1$-expressing MDA-MB-231 and Hs578T cells (3.5-fold increase only for miR-429 in Hs578T cells) (Figure 2D; Additional file 8, Figure S4A). In addition, reduction of endogenous ER $\beta 1$ expression in MDA-MB-231 and Hs578T cells by ER $\beta$ siRNA led to a decrease in the expression of miR-200a, miR-200b and miR-429 (Figure 2E; Additional file 8, Figure S4B). In contrast to the cluster of miR-200b-200a-429, the cluster miR-200c-141 and the miR-205 were unchanged in ER $\beta 1$ expressing MDA-MB-231 cells (Additional file 9, Figure S5). We also examined how important is the up-regulation of miR-200a-b-429 for the ER $\beta 1$-mediated repression of EMT. We transfected the ER $\beta 1$-expressing MDA-MB-231 cells with inhibitors of miR-200a, miR-200b and miR-429 and assessed the level of functional knockdown of miR200a-b-429 by a reporter assay, in which the complementary sequence of miR200a-b-429 was introduced in the 3' UTR of a luciferase reporter gene. Transfection of the cells with miR200a-b-429 inhibitors resulted in a more than two-fold increase in luciferase activity compared with the negative control inhibitor suggesting that a greater than $50 \%$ inhibition of the miR200a-b-429 function had been achieved by the miR200a-b-429 inhibitors (Figure 2F). Inhibition of miR200a-b-429 partially reversed the ER $\beta 1$ mediated epithelial phenotype and caused a 50\% reduction in the expression of E-cadherin (Figure 2F). These data strengthen the role of ER $\beta 1$ in regulating EMT and suggest a mechanism through which the receptor may regulate E-cadherin expression.

\section{ERß1 inhibits EMT by repressing EGFR signaling}

EGFR that is overexpressed in MDA-MB-231 and Hs578T cells has been associated with poor survival in basal-like breast cancers (Additional file 10, Figure S6). Overexpression of EGFR is known to promote migration in breast cancer cells [36,37]. Activation of EGFR following ligand binding results in phosphorylation and activation of extracellular-signal-regulated kinases (ERKs) [38]. Activation of ERK2 has recently been shown to promote EMT by inducing the expression of the transcriptional repressors of E-cadherin ZEB-1 and SIP-1 [17,18]. Given the repression of ZEB-1 and SIP-1 expression observed in ER $\beta 1$-expressing MDA-MB-231 and Hs578T cells, we examined whether ER $\beta 1$ inhibits EMT by down-regulating EGFR signaling. Induction of ER $\beta 1$ expression caused a strong 


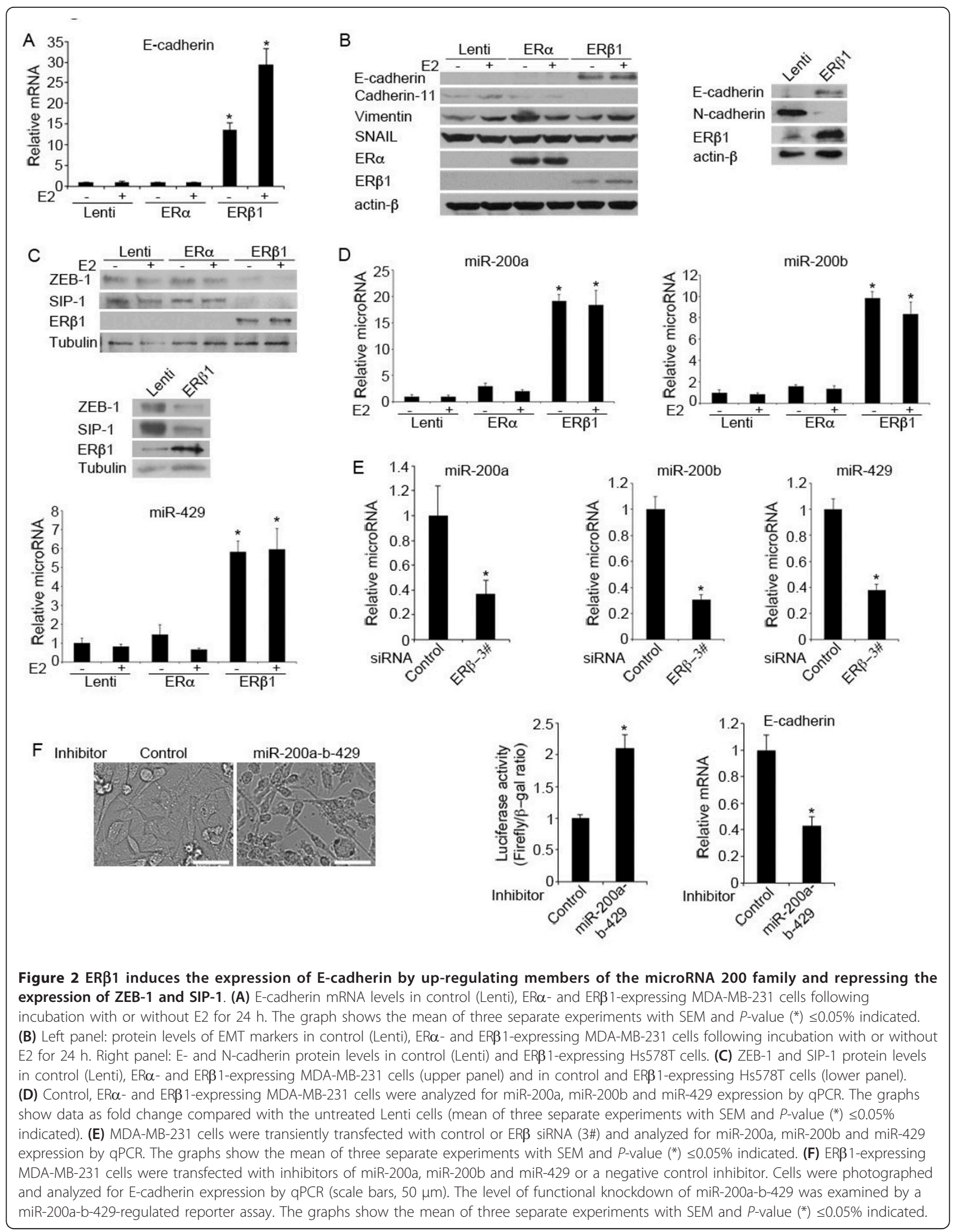


reduction in the EGFR protein levels in MDA-MB-231 and Hs578T cells and decreased the phosphorylation of ERK1/2 as assessed by immunoblotting using an ERK1/2 phospho-specific antibody (Figure 3A, B). Furthermore, reduction of endogenous ER $\beta 1$ expression in MDA-MB231 cells led to up-regulation of EGFR (Figure 3C). Analysis of EGFR mRNA by qPCR showed the same levels in control and ER $\beta 1$-expressing cells as well as in cells where ER $\beta 1$ had been knocked down, suggesting that ER $\beta 1$ does not regulate the transcription of EGFR gene (Additional file 6, Figure S2C). To test whether the ER $\beta 1$-EGFR interaction is a critical regulator of EMT in basal-like breast cancer cells, we treated the ER $\beta 1$-expressing cells with EGF or the EMT inducer TGF- $\beta 1$ for $24 \mathrm{~h}$. For the same purpose, we stably transfected the ER $\beta 1$-expressing MDAMB-231 cells with an empty vector or a plasmid that encodes wild-type EGFR. As expected, treatment of the cells with EGF restored the phosphorylation of ERK1/2, decreased the cell-cell contact observed in the ER $\beta 1$ expressing cells and abolished the ER $\beta 1$-mediated upregulation of miR-200a-200b-429 and the increased levels of E-cadherin (Figure 3D-F, 3G). In contrast, treatment of the cells with TGF- $\beta 1$, for the same time period as for EGF, failed to reverse the ER $\beta 1$-induced phenotype in MDA-MB-231 cells (Figure 3D, F, G). As in the case of EGF treatment, EGFR overexpression induced a more fibroblastoid morphology in ER $\beta 1$-expressing cells, which was accompanied by down-regulation of E-cadherin (Figure $3 \mathrm{H}$ ).

\section{$E R \beta 1$ induces degradation of EGFR by enhancing the EGFR-c-Cbl interaction}

Given that ER $\beta 1$ altered only the protein but not the mRNA levels of EGFR, we set out to investigate whether ER $\beta 1$ regulates EGFR at a post-transcriptional level. Specifically, we hypothesized that ER $\beta 1$ induces degradation of the EGFR protein. EGFR degradation occurs through a process that includes ubiquitylation of the receptor, accelerated endocytosis and degradation by proteasomal and lysosomal hydrolases [39]. In chase experiments, expression of ER $\beta 1$ reduced the half-life of EGFR suggesting that EGFR protein turnover was enhanced by ER $\beta 1$ (Figure 4A). Treatment of the cells with the proteasome inhibitor MG-132 inhibited the ER $\beta 1$-dependent reduction in EGFR protein abundance (Figure 4B) confirming that EGFR down-regulation in ER $\beta 1$-expressing cells was due to increased degradation. Given that ubiquitylation is an important step in the degradation of EGFR, we carried out ubiquitylation assays to test whether ER $\beta 1$ induces ubiquitylation of EGFR. Interestingly, the levels of the ubiquitylated EGFR were dramatically increased in ER $\beta 1$-expressing MDA-MB-231 and Hs578T cells (Figure 4C). Furthermore, the ubiquitylated EGFR was decreased when ER $\beta 1$ was knocked down in
MDA-MB-231 cells (Figure 4D). Given that ubiquitylation of the activated EGFR is mediated by members of the Cbl family of RING domain E3 ubiquitin ligases, including the c-Cbl [40], we examined whether ER $\beta 1$ promotes ubiquitylation of EGFR by inducing its association with c-Cbl. In control MDA-MB-231 cells, immunoprecipitation of EGFR under nondenaturing conditions showed a rapid but transient recruitment of c-Cbl to EGFR with a barely detectable c-Cbl-EGFR association at 45 minutes following EGF induction. ER $\beta 1$-expressing MDA-MB-231 cells showed enhanced and more sustained c-Cbl-EGFR association with high amounts of c-Cbl recruited to EGFR even at 45 minutes following EGF induction (Figure 4E). These results strengthen our hypothesis that ER $\beta 1$ down-regulates EGFR by inducing its degradation.

\section{ER $\beta 1$ inhibits invasion of breast cancer cells in vivo}

To study the role of ER $\beta 1$ in regulating early events of the metastatic cascade, we used a zebrafish tumor model in which the $T g(f l k 1: E G F P) /$ casper zebrafish embryos were implanted with the highly metastatic human MDA-MB-231 cells. The $T g(f l k 1: E G F P) /$ casper embryos lack pigmentation and express green fluorescent protein (GFP) in the vascular system for direct visualization of vascular development [41]. Both control (Lenti) and ER $\beta 1$-expressing MDA-MB-231 cells were stably transfected with either DsRed or AmCyan fluorescent proteins. A mixture of either control-DsRed and ER $\beta 1$-AmCyan cells or control-AmCyan and ER $\beta 1$-DsRed cells were injected into the perivitelline cavity at 48 hours post-fertilization (hpf), at which time the immune system of the fish is not yet developed. The zebrafish were first imaged $3 \mathrm{~h}$ after implantation (Figure 5A, B, upper panels). Invasion and dissemination of DsRed and AmCyan cells were monitored daily in zebrafish. At five days post-injection (dpi), both DsRed and AmCyan MDA-MB-231 control cells had significantly disseminated away from the primary injection site, including the head and the tail regions, whereas ER $\beta 1$-expressing MD-MB-231 cells labeled with either DsRed or AmCyan remained at the primary site (Figure 5A-D). Out of 45 embryos that were injected with both control and ER $\beta 1$-expressing cells, 27 embryos had disseminated control cells, and only 2 embryos had disseminated control and ER $\beta 1$-expressing cells. However, in these two zebrafish, the ratio of control:ER $\beta 1$ disseminated cells was more than 8:1 (Figure 5E; Additional file 11, Figure S7). Our results show that the difference in metastatic potential between the control and the ER $\beta 1$-expressing cells is due to their different capacity to invade and disseminate.

\section{ER $\beta 1$ and E-cadherin levels are positively correlated in breast cancers}

Since ER $\beta 1$ induces the expression of E-cadherin in breast cancer cells, we next examined the correlation of 
A

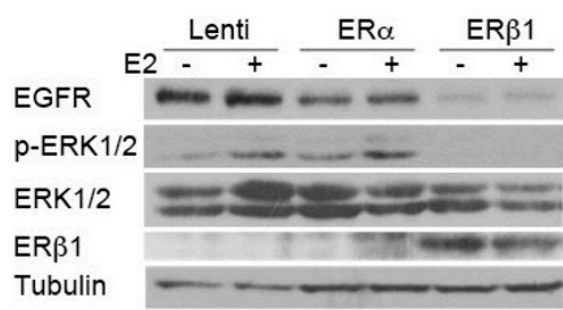

B

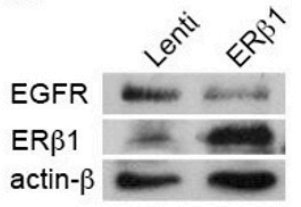

C

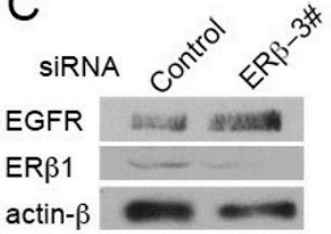

D

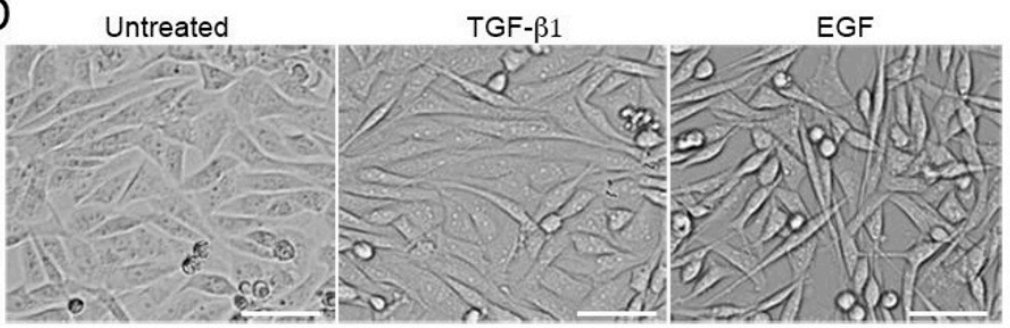

E

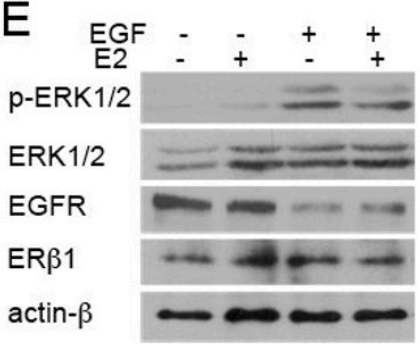

$\mathrm{F}$

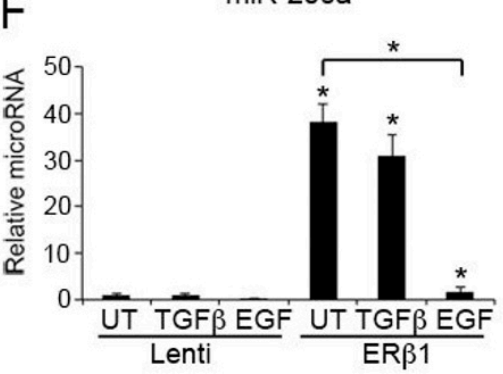

$\operatorname{miR}-429$

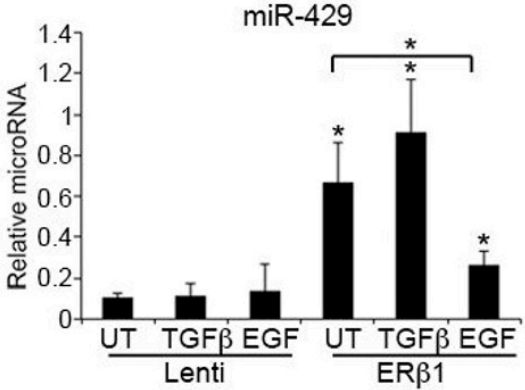

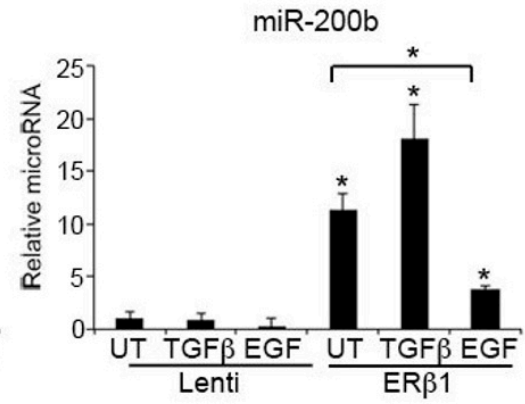

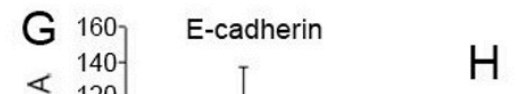

$\mathrm{H}$

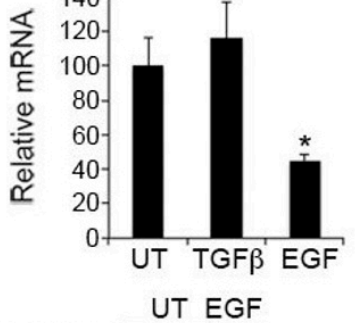

E-cadherin UT EGF actin- $\beta$
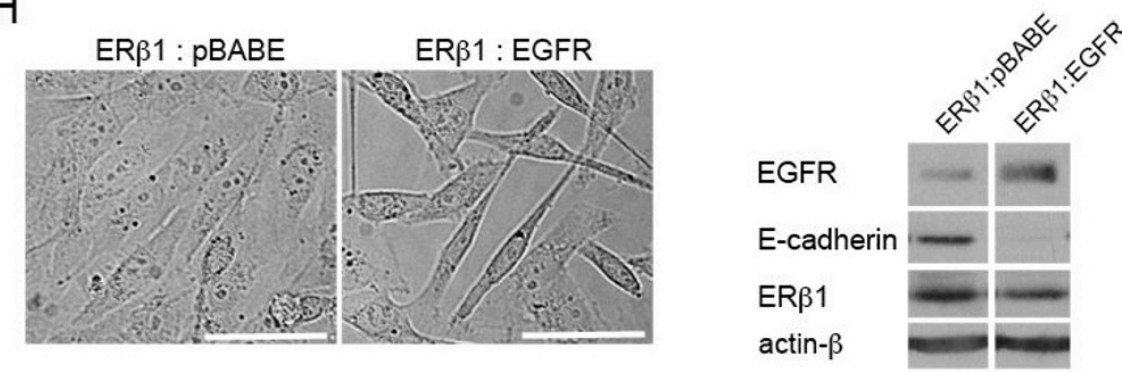

Figure 3 EGFR promotes EMT and its down-regulation is involved in ERB1-induced E-cadherin expression. (A) EGFR, total ERK1/2 and phospho-ERK1/2 levels in control (Lenti), ER $\alpha$ - and ERß1-expressing MDA-MB-231 cells following incubation with or without E2 for 24 h. (B) EGFR protein levels in control (Lenti) and ERß1-expressing Hs578T cells. (C) EGFR protein levels in MDA-MB-231 cells transiently transfected with control or ERß siRNA (3\#). (D) ERß1-expressing MDA-MB-231 cells were incubated in absence or presence of $5 \mathrm{ng} / \mathrm{ml}$ TGF- $\beta 1$ or $10 \mathrm{ng} / \mathrm{ml}$ EGF for $24 \mathrm{~h}$ and photographed (scale bars, $50 \mu \mathrm{m}$ ). (E) ERß1-expressing MDA-MB-231 cells were incubated in absence or presence of $10 \mathrm{ng} / \mathrm{ml}$ EGF for $24 \mathrm{~h}$ and analyzed for the expression of EGFR, total ERK1/2 and phospho-ERK1/2 by immunoblotting. Note that the decreased EGFR levels following EGF treatment is due to increased degradation. (F) miR-200a, miR-200b and miR-429 levels in control (Lenti) and ERß1-expressing MDA-MB-231 cells following incubation with $5 \mathrm{ng} / \mathrm{ml} \mathrm{TGF- \beta 1}$ or $10 \mathrm{ng} / \mathrm{ml}$ EGF for $24 \mathrm{~h}$. The graph shows the data as fold change compared with the untreated Lenti cells (mean of three separate experiments ( \pm SEM) with $P$-value $\left(^{*}\right) \leq 0.05 \%$ ). (G) E-cadherin mRNA and protein levels in ER $\beta 1$-expressing MDA-MB-231 cells following incubation with $5 \mathrm{ng} / \mathrm{ml}$ TGF- $\beta 1$ or $10 \mathrm{ng} / \mathrm{ml}$ EGF for $24 \mathrm{~h}$. The graph shows the mean of three separate experiments with SEM and $P$-value $\left(^{*}\right) \leq 0.05 \%$ indicated. $(\mathbf{H})$ ERß1-expressing MDA-MB-231 cells were stably co-transfected with an empty pBABE vector (ERß1:pBABE cells) or the pBABE-EGFR plasmid (ERß1:EGFR cells), photographed and analyzed for EGFR, E-cadherin and ERß1 expression by immunoblotting (scale bars, $50 \mu \mathrm{m}$ ). 


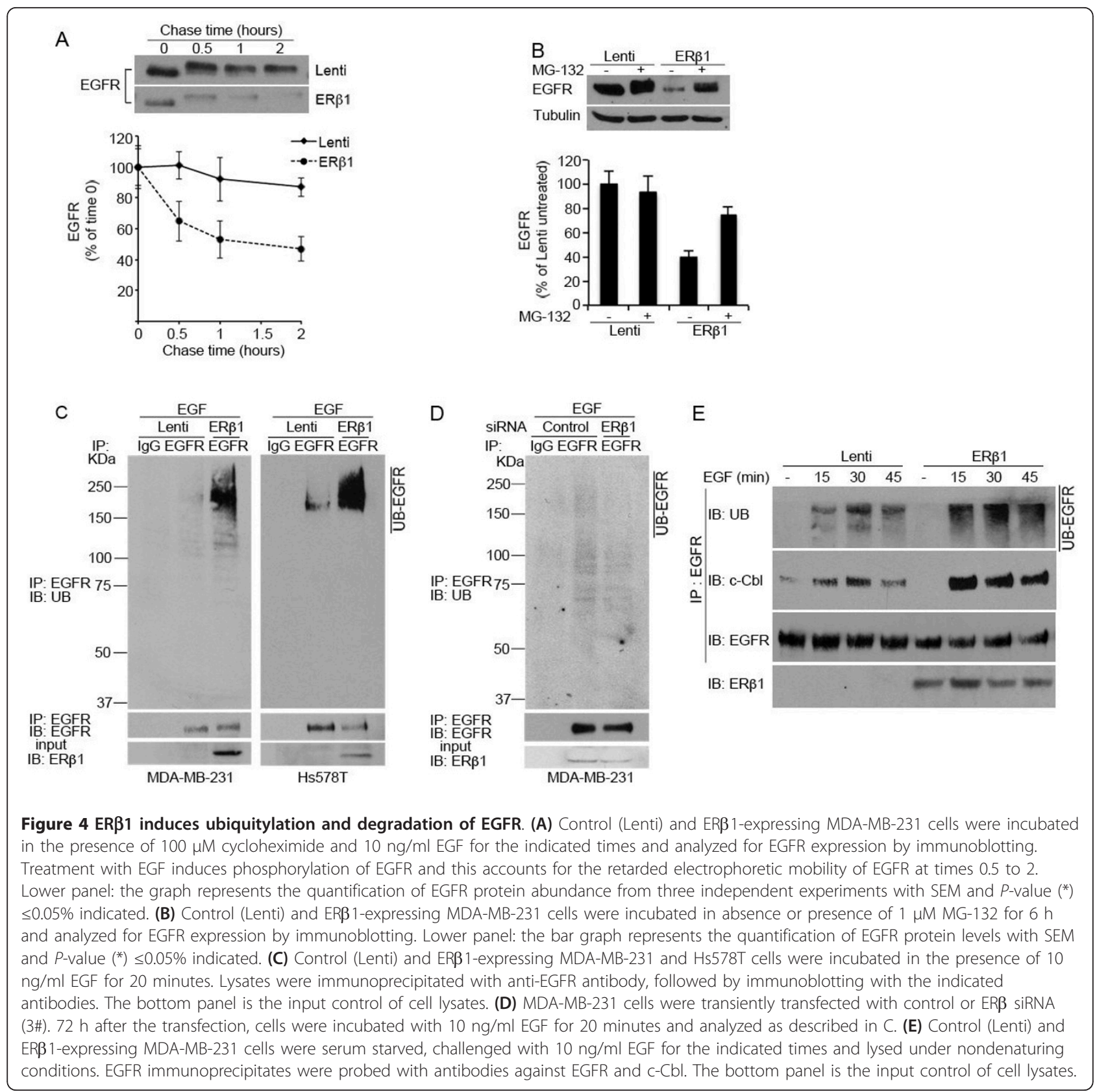

ER $\beta 1$ and E-cadherin protein levels in breast tumor samples. We utilized a tissue microarray of 240 primary untreated and unselected breast cancers. Clinical history and tumor characteristics (tumor type, age, size, grade, lymph node status, ER $\alpha$, PR and HER2 status) that were available for 238 cases are summarized in Additional file 3, Table S2. ER $\beta 1$ and E-cadherin protein levels were determined by IHC using an ER $\beta 1$ specific antibody (PPG5/10; DAKO). The specificity of the ER $\beta 1$ antibody was confirmed by immunocytochemistry (Additional file 12 Figure S8A, B). A total of 32 samples were excluded from the analysis due to the absence of tumor or presence of benign tumor in the core. We carried out Pearson's correlation analysis with the information of ER $\beta 1$ and E-cadherin expression from the 208 cancers. Pearson's correlation analysis showed a strong positive correlation between ER $\beta 1$ and E-cadherin expressions $(P=3.41 \mathrm{e}-4)$ (Figure 6A).

To better understand the correlation between ER $\beta 1$ and E-cadherin, we divided the breast cancer samples into three groups based on ER $\beta 1$ levels defined by their expression scores and studied the difference of E-cadherin expression among the three groups. The expression of E-cadherin in each group was represented by its median 


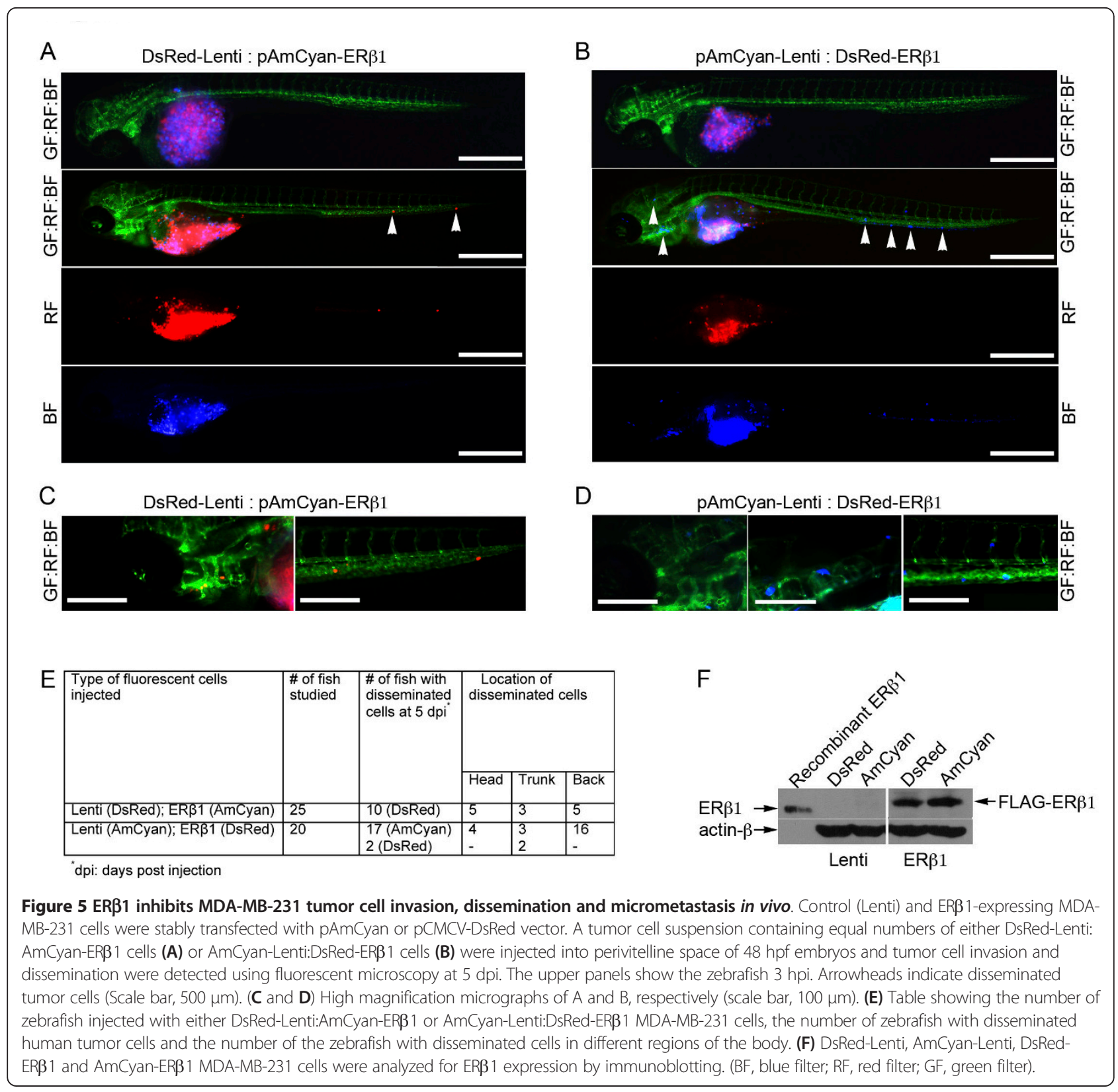

score (Figure 6C) or positive percentage (Figure 6D). As shown in Figure $6 \mathrm{C}$, the median scores of E-cadherin in tumors expressing low levels of ER $\beta 1$ were significantly smaller than in those with higher ER $\beta 1$ levels. Similarly, the positive percentage analysis for E-cadherin showed a positive correlation with ER $\beta 1$ levels (Figure 6D). These results are consistent with our findings that ER $\beta 1$ up-regulates E-cadherin in breast cancer cell lines.

\section{Discussion}

Although basal-like breast cancers in general are associated with relatively poor prognosis, they are heterogeneous, including diverse subgroups in terms of chemotherapy response and risk of developing distant metastases [2,6,7]. Interestingly, ER $\beta 1$ positivity has recently been associated with better survival in triple-negative cancers that were treated with tamoxifen and inversely correlated with the expression of EGFR, an important marker in the immunohistochemical identification of basal-like cancers [24,25,36].

One process that has been attributed to primary tumor metastasis is EMT. Here we examined whether ER $\beta 1$ through regulating EMT can influence invasion and metastasis in basal-like cancers. ER $\beta 1$ repressed the mesenchymal spindle-shaped morphology of the MDA-MB-231 and Hs578T cells and enhanced cell-cell contact. ER $\beta 1$ altered the morphology of these cells in the absence of ligand. 


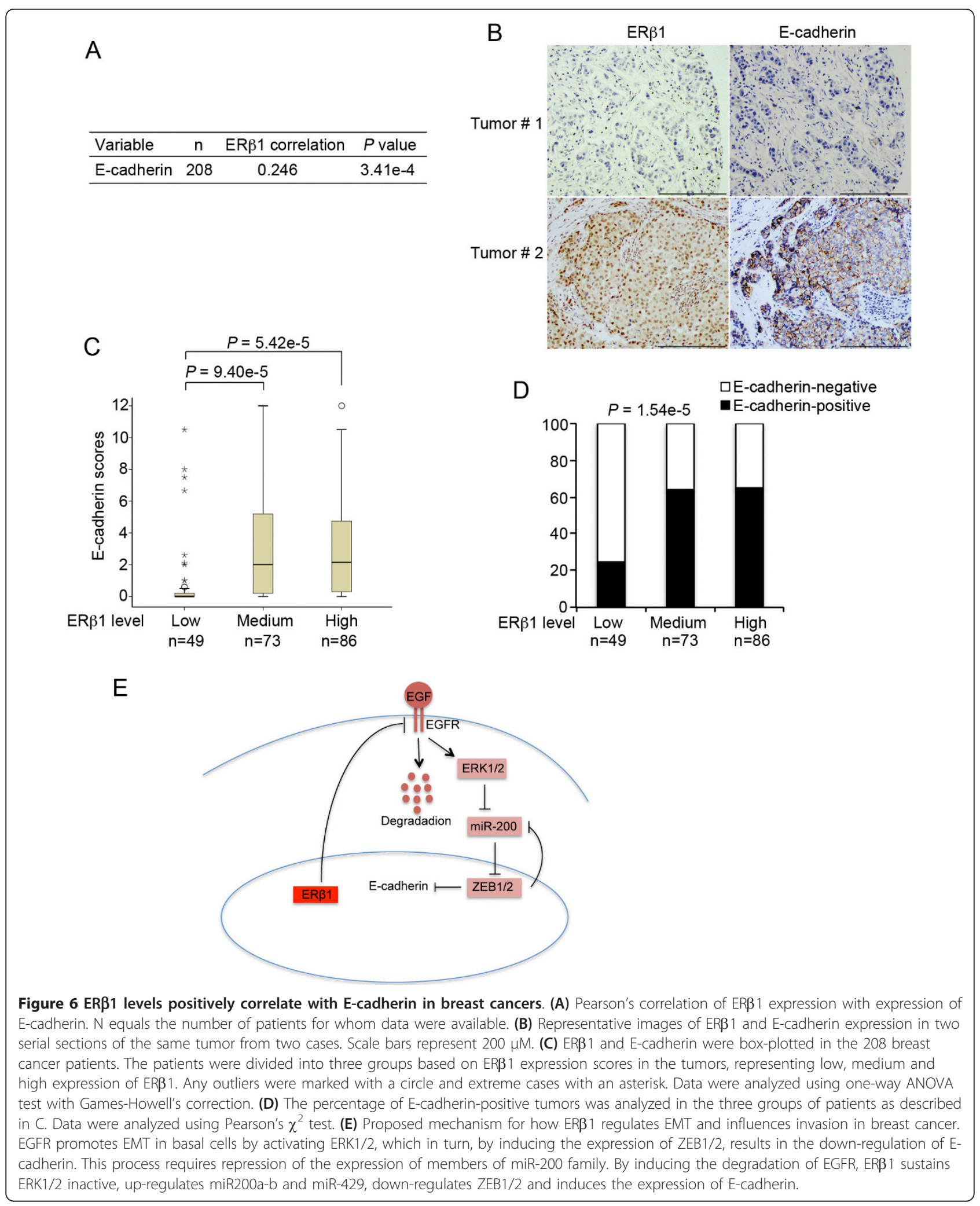


This is in agreement with our previous data showing increased transcriptional activity following expression of ER $\beta 1$ in MDA-MB-231 cells in the absence of ER $\beta$ agonists. The increased transcriptional activity in the absence of ligand was correlated with the phosphorylation of ER $\beta 1$ at ser-87 [28]. As a result of the changes in the morphology, ER $\beta 1$ inhibited migration and reduced the invasiveness of MDA-MB-231 cells. When control and ER $\beta 1$ expressing cells were injected into zebrafish embryos, only the control cells disseminated to distant sites suggesting that ER $\beta 1$ functions as a crucial anti-invasive factor. Given that expression of EMT markers and cadherin switching have been reported to correlate with the basal-like phenotypes in in vitro model systems and in specimens from patients [7], we examined whether ER $\beta 1$ inhibits invasion and migration by regulating EMT in cells with basal characteristics. ER $\beta 1$ was found to induce the expression of Ecadherin by inhibiting its transcriptional repressors ZEB1/2 and up-regulating the miR-200a, miR-200b and miR-429, which correlate with the epithelial breast cancer phenotype (Figure 6E).

ERK2 has recently been shown to affect the ZEB1/2 regulatory pathway of E-cadherin expression in human mammary cells $[17,18]$. ERK $1 / 2$ are activated by diverse pathways including that initiated by EGFR [38]. Overexpression of EGFR promotes migration and invasion of basal cells and its expression correlates with poor survival in basal-like cancers [36,37]. Since ER $\beta 1$ was found to inhibit EMT by down-regulating the ZEB1/2 pathway in basal-like cells, we tested whether repression of EGFR and ERK1/2 signaling are involved in ER $\beta 1$-mediated up-regulation of E-cadherin and the subsequent inhibition of cell migration and invasion. Indeed, ER $\beta 1$ induced a decrease in EGFR protein levels without altering the transcription of the EGFR gene followed by down-regulation of the phosphorylated ERK1/2 forms. Induction of EGFR signaling in ER $\beta 1$-expressing cells through up-regulation of EGFR or treatment of the cells with EGF reversed the ER $\beta 1$-dependent epithelial phenotype, suggesting that EGFR is a critical factor in the ER $\beta 1$-mediated regulation of EMT.

Given that inhibition of transcription was not involved in ER $\beta 1$-mediated down-regulation of EGFR, we examined whether ER $\beta 1$ promotes degradation of the tyrosine kinase receptor. EGFR degradation is a complex process that involves ubiquitylation of the activated receptor by the E3 enzyme $\mathrm{Cbl}$ and subsequent proteolysis by proteosomal and lysosomal hydrolases [39]. ER $\beta 1$ was found to induce ubiquitylation and degradation of EGFR by enhancing the EGFR-c-Cbl association. Ubiquitylation is an important process of a negative regulatory circuit that terminates EGFR signaling by targeting the receptor for degradation [42]. Our data show for first time that ER $\beta 1$, by inducing these negative feedback pathways, is likely to exert a role of EGFR inhibitor and tumor suppressor function.

Interestingly, it has recently been shown that ER $\beta$ decreases the expression of insulin-like growth factor IImRNA binding protein 3 (IMP-3) by repressing EGFR transcription in MDA-MB-231 cells [43]. In our study, the transcription of EGFR was not altered when ER $\beta 1$ was expressed or knocked down in MDA-MB-231 and Hs578T basal-like cells. Instead, as mentioned above, ER $\beta 1$ promotes degradation of EGFR by inducing its ubiquitylation in both MDA-MB-231 and Hs578T cells.

By examining 208 clinical breast cancer specimens, we found that the expression of ER $\beta 1$ was significantly associated with the expression of E-cadherin. This correlation has not previously been reported. However, since the discovery of ER $\beta$, it has been shown that the association of ER $\beta$ to other clinicopathological indicators is likely to be divergent in different breast cancer cohorts analyzed by IHC using different ER $\beta$ antibodies. The tumor cohort examined in our study included a different number of HER2-positive (14.5\%) and probably triple-negative breast cancers compared with the cohorts utilized in some of the recent studies that examined large number of samples with well-validated antibodies (HER2-positive, Honma et al. 2008: 5.25\% and Novelli et al. 2008: 31.9\%) [24,25, $44,45]$. Such differences in the characteristics of the clinical cancer samples as well as differences in the specificity of the ER $\beta$ antibodies used in these studies, may explain why the correlation between ER $\beta 1$ and E-cadherin expression has not been previously observed. This positive ER $\beta 1$-E-cadherin association is consistent with the ER $\beta 1$ mediated up-regulation of E-cadherin observed in breast cancer cells. It is possible that there are some limitations in the relevance of these results since the level of ER $\beta 1$ expression achieved in our cells may not reflect the levels of expression seen in clinical samples. Despite these limitations, taken together, our results propose a role for ER $\beta 1$ in up-regulating E-cadherin in breast cancer cells. This suggests that the low ER $\beta 1$ levels may be the primary cause of low E-cadherin expression and induction of EMT in some breast cancers. Since EMT correlates with a group of basal-like breast cancers that often develop metastases in distant sites [7], ER $\beta 1$ may play a crucial role in repressing invasive behavior and inhibiting metastasis in this subset of breast cancers. Our data show that ER $\beta 1$ impedes EMT and influences invasion by downregulating EGFR, which is expressed in basal-like cancers. These results strengthen the possibility that ER $\beta 1$ can help to identify patients with basal-like cancer with lower risk to develop metastasis.

\section{Conclusions}

Basal-like breast cancers that show unfavorable prognosis and often develop distant metastases are associated 
with EMT. Our findings indicate that ER $\beta 1$ inhibits EMT and reduces the invasiveness of basal-like breast cancer cells by up-regulating the epithelial marker Ecadherin. ER $\beta 1$ induces the expression of E-cadherin by down-regulating EGFR, an oncogenic factor that is expressed in basal-like cancers. ER $\beta 1$ was found to terminate EGFR signaling by targeting the receptor for degradation. Our data support the notion that ER $\beta 1$ can serve as a clinical marker to identify patients with basallike cancer that have lower risk to develop metastasis.

\section{Additional material}

Additional file 1: Table 1S. Oligonucleotides used in qPCR. The table

lists the sequences of the oligonucleotides used in GPCR.

Additional file 2: Supplementary materials and methods. The file

contains supplementary information for the zebrafish lines used in xenotransplantation study.

Additional file 3: Table S2. Clinicopathological characteristics of 238 breast cancer patients. The table contains the clinicopathological characteristics of 238 breast cancer patients.

Additional file 4: Figure S1. Functional analysis of ER $\alpha$ and ER $\beta 1$ in MDA-MB-231 cells. The figure shows the functionality of ER $\alpha$ and ER $\beta 1$ in MDA-MB-231 cells.

Additional file 5: Supplementary figure legends. The file contains the figure legends for the supplementary figures S1-S8.

Additional file 6: Figure S2. Regulation of EMT markers by ER $\beta 1$. Description: The figure shows how ER 1 regulates some of the EMT markers.

Additional file 7: Figure S. ER $\beta 1$ does not alter the intracellular localization of SNAIL. The figure shows how ERß1 affects the intracellular localization of SNAIL.

Additional file 8: Figure S4. ER $\beta 1$ regulates the expression of miR200a, miR-200b and miR-429. The figure shows the regulation of miR200a, miR-200b and miR-429 by ERß1 in Hs578T cells.

Additional file 9: Figure S5. Regulation of miR-200c, miR-141 and miR-205 by ER $\beta 1$. The figure shows the regulation of miR-200c, miR-141 and miR-205 by ERß1.

Additional file 10: Figure S6. Differences in the expression of EGFR between the ER $\alpha$-positive (MCF-7) and the triple-negative (MDA-MB231 and Hs578T) cells. The figure shows the different expression levels of EGFR in MCF-7, MDA-MB-231 and Hs578T breast cancer cells.

Additional file 11: Figure S7. Dissemination patterns of ER $\beta 1$ expressing cells in zebrafish. The figure shows the dissemination patterns of ER $\beta 1$-expressing cells in zebrafish.

Additional file 12: Figure S8. Validation of the anti-ER $\beta 1$ antibody by immunocytochemistry. The figure shows the specificity of the antiERß 1 antibody used in immunohistochemistry.

\section{Abbreviations}

BSA: bovine serum albumin; CK: cytokeratin; DCC: dextran-coated charcoal; DCIS: ductal carcinoma in situ; dpi: days post-injection; EGFR: epidermal growth factor receptor; EMT: epithelial to mesenchymal transition; ERa: estrogen receptor $\alpha$; ERß: estrogen receptor $\beta$; ERKs: extracellular-signalregulated kinases; FCS: fetal calf serum; GFP: green fluorescent protein; hpf: hours post-fertilization; IACUC: Institutional Animal Care and Use Committee; IHC: immunohistochemistry; IMP-3: insulin-like growth factor II mRNA binding protein 3; PBS: phosphate-buffered saline; RT: room temperature; RTPCR: reverse transcription polymerase chain reaction; TGF- $\beta$ : transforming growth factor $\beta$

\section{Acknowledgements}

We thank Igor Bado, Anders Strom, Cecilia Williams, Ivan Nalvarte, Luisa A. Helguero and Ryan Butler for technical help, and Sang-Hyuk Chung and Chiara Gabbi for help with statistical analysis. This paper was supported by grants from The Emerging Technology Fund of Texas, CPRIT, The Welch Foundation (E-0004) and The Swedish Cancer Society.

\section{Author details}

'Department of Biology and Biochemistry, Center for Nuclear Receptors and Cell Signaling, University of Houston, 3605 Cullen Blvd., Houston, TX 77204, USA. ${ }^{2}$ Department of Surgery and Molecular Oncology, University of Dundee, DD1 9SY Dundee, UK. ${ }^{3}$ Department of Pathology, The University of Texas MD Anderson Cancer Center, 1515 Holcombe Blvd., Houston, TX 77030, USA. ${ }^{4}$ Department of Breast Medical Oncology, The University of Texas MD Anderson Cancer Center, 1515 Holcombe Blvd., Houston, TX 77030, USA.

\section{Authors' contributions}

$C T$ conceived, designed and supervised the study, performed or participated in all experiments, their analysis and interpretation, and wrote the manuscript. JAG supervised research and edited the manuscript. GR participated in the in vitro experiments with the cell lines and in the immunohistochemical staining of the tissue sections. FN participated in most of the cell-based studies. $\mathrm{RH}$ and CWM performed the experiments with the transplantation of human cells in zebrafish. MB supervised the zebrafish xenotransplantation assay and participated in editing the manuscript. AK assisted in the experiments with the microRNAs. PQ assisted in the clinical data analysis. SK participated in the design of the clinical study and evaluated the immunohistochemical staining. FJE and AT participated in the design of the clinical study and supervised the analysis of the clinical breast cancer specimens. All authors read and approved the final manuscript.

\section{Competing interests}

The authors declare that they have no competing interests.

Received: 1 July 2012 Revised: 19 September 2012

Accepted: 12 November 2012 Published: 16 November 2012

\section{References}

1. Perou CM, Sorlie T, Eisen MB, van de Rijn M, Jeffrey SS, Rees CA, Pollack JR, Ross DT, Johnsen $H$, Akslen LA, Fluge $O$, Pergamenschikov A, Williams $C$, Zhu SX, Lonning PE, Borresen-Dale AL, Brown PO, Botstein D: Molecular portraits of human breast tumours. Nature 2000, 406:747-752.

2. Prat A, Perou CM: Deconstructing the molecular portraits of breast cancer. Mol Oncol 2011, 5:5-23.

3. Curtis C, Shah SP, Chin SF, Turashvili G, Rueda OM, Dunning MJ, Speed D, Lynch AG, Samarajiwa S, Yuan Y, Graf S, Ha G, Haffari G, Bashashati A, Russell R, McKinney S, Langerod A, Green A, Provenzano E, Wishart G, Pinder S, Watson P, Markowetz F, Murphy L, Ellis I, Purushotham A, Borresen-Dale AL, Brenton JD, Tavare S, Caldas C, et al: The genomic and transcriptomic architecture of 2,000 breast tumours reveals novel subgroups. Nature 2012, 486:346-352.

4. Sorlie T, Tibshirani R, Parker J, Hastie T, Marron JS, Nobel A, Deng S, Johnsen H, Pesich R, Geisler S, Demeter J, Perou CM, Lonning PE, Brown PO, Borresen-Dale AL, Botstein D: Repeated observation of breast tumor subtypes in independent gene expression data sets. Proc Natl Acad Sci USA 2003, 100:8418-8423.

5. Rakha E, Ellis I, Reis-Filho J: Are triple-negative and basal-like breast cancer synonymous? Clin Cancer Res 2008, 14:618-619, author reply 618.

6. Kreike $B$, van Kouwenhove $M$, Horlings $H$, Weigelt $B$, Peterse $H$, Bartelink $H$, van de Vijver MJ: Gene expression profiling and histopathological characterization of triple-negative/basal-like breast carcinomas. Breast Cancer Res 2007, 9:R65.

7. Sarrio D, Rodriguez-Pinilla SM, Hardisson D, Cano A, Moreno-Bueno G, Palacios J: Epithelial-mesenchymal transition in breast cancer relates to the basal-like phenotype. Cancer Res 2008, 68:989-997.

8. Yori JL, Seachrist DD, Johnson E, Lozada KL, Abdul-Karim FW, Chodosh LA, Schiemann WP, Keri RA: Kruppel-like factor 4 inhibits tumorigenic progression and metastasis in a mouse model of breast cancer. Neoplasia 2011, 13:601-610. 
9. Thiery JP: Epithelial-mesenchymal transitions in tumour progression. Nat Rev Cancer 2002, 2:442-454.

10. Hazan RB, Qiao R, Keren R, Badano I, Suyama K: Cadherin switch in tumor progression. Ann N Y Acad Sci 2004, 1014:155-163.

11. Maeda M, Johnson KR, Wheelock MJ: Cadherin switching: essential for behavioral but not morphological changes during an epithelium-tomesenchyme transition. J Cell Sci 2005, 118:873-887.

12. Bolos V, Peinado H, Perez-Moreno MA, Fraga MF, Esteller M, Cano A: The transcription factor Slug represses E-cadherin expression and induces epithelial to mesenchymal transitions: a comparison with Snail and E47 repressors. J Cell Sci 2003, 116:499-511.

13. Comijn J, Berx G, Vermassen P, Verschueren K, van Grunsven L, Bruyneel E, Mareel M, Huylebroeck D, van Roy F: The two-handed E box binding zinc finger protein SIP1 downregulates E-cadherin and induces invasion. Mol Cell 2001, 7:1267-1278.

14. Eger A, Aigner K, Sonderegger S, Dampier B, Oehler S, Schreiber M, Berx G, Cano A, Beug H, Foisner R: DeltaEF1 is a transcriptional repressor of Ecadherin and regulates epithelial plasticity in breast cancer cells. Oncogene 2005, 24:2375-2385.

15. Yang J, Mani SA, Donaher JL, Ramaswamy S, Itzykson RA, Come C, Savagner P, Gitelman I, Richardson A, Weinberg RA: Twist, a master regulator of morphogenesis, plays an essential role in tumor metastasis. Cell 2004, 117:927-939.

16. Gregory PA, Bert AG, Paterson EL, Barry SC, Tsykin A, Farshid G, Vadas MA, Khew-Goodall Y, Goodall GJ: The miR-200 family and miR-205 regulate epithelial to mesenchymal transition by targeting ZEB1 and SIP1. Nat Cell Biol 2008, 10:593-601.

17. Shin S, Blenis J: ERK2/Fra1/ZEB pathway induces epithelial-tomesenchymal transition. Cell Cycle 2010, 9:2483-2484.

18. Shin S, Dimitri CA, Yoon SO, Dowdle W, Blenis J: ERK2 but not ERK1 induces epithelial-to-mesenchymal transformation via DEF motifdependent signaling events. Mol Cell 2010, 38:114-127.

19. Thomas C, Gustafsson JA: The different roles of ER subtypes in cancer biology and therapy. Nat Rev Cancer 2011, 11:597-608.

20. Wang X, Belguise K, Kersual N, Kirsch KH, Mineva ND, Galtier F, Chalbos D, Sonenshein GE: Oestrogen signalling inhibits invasive phenotype by repressing RelB and its target BCL2. Nat Cell Biol 2007, 9:470-478.

21. Ye Y, Xiao Y, Wang W, Yearsley K, Gao JX, Shetuni B, Barsky SH: ERalpha signaling through slug regulates E-cadherin and EMT. Oncogene 29:1451-1462.

22. Mak P, Leav I, Pursell B, Bae D, Yang X, Taglienti CA, Gouvin LM, Sharma VM, Mercurio AM: ERbeta impedes prostate cancer EMT by destabilizing HIF-1alpha and inhibiting VEGF-mediated snail nuclear localization: implications for Gleason grading. Cancer Cell 17:319-332.

23. Leung YK, Lam HM, Wu S, Song D, Levin L, Cheng L, Wu CL, Ho SM: Estrogen receptor beta2 and beta5 are associated with poor prognosis in prostate cancer, and promote cancer cell migration and invasion. Endocr Relat Cancer 17:675-689.

24. Honma N, Horii R, Iwase T, Saji S, Younes M, Takubo K, Matsuura M, Ito $Y$, Akiyama F, Sakamoto G: Clinical importance of estrogen receptor-beta evaluation in breast cancer patients treated with adjuvant tamoxifen therapy. J Clin Oncol 2008, 26:3727-3734.

25. Marotti JD, Collins LC, Hu R, Tamimi RM: Estrogen receptor-beta expression in invasive breast cancer in relation to molecular phenotype: results from the Nurses' Health Study. Mod Pathol 2010, 23:197-204.

26. Leygue ER, Watson PH, Murphy LC: Estrogen receptor variants in normal human mammary tissue. J Natl Cancer Inst 1996, 88:284-290.

27. Hartman J, Edvardsson K, Lindberg K, Zhao CY, Williams C, Strom A, Gustafsson JA: Tumor repressive functions of estrogen receptor beta in SW480 colon cancer cells. Cancer Res 2009, 69:6100-6106.

28. Thomas CG, Strom A, Lindberg K, Gustafsson JA: Estrogen receptor beta decreases survival of p53-defective cancer cells after DNA damage by impairing G(2)/M checkpoint signaling. Breast Cancer Res Treat 2011, 127:417-427.

29. Saji S, Jensen EV, Nilsson S, Rylander T, Warner M, Gustafsson JA: Estrogen receptors alpha and beta in the rodent mammary gland. Proc Natl Acad Sci USA 2000, 97:337-342.

30. Skliris GP, Munot K, Bell SM, Carder PJ, Lane S, Horgan K, Lansdown MR, Parkes AT, Hanby AM, Markham AF, Speirs V: Reduced expression of oestrogen receptor beta in invasive breast cancer and its re-expression using DNA methyl transferase inhibitors in a cell line model. J Pathol 2003, 201:213-220.

31. Shaaban AM, O'Neill PA, Davies MP, Sibson R, West CR, Smith PH, Foster CS: Declining estrogen receptor-beta expression defines malignant progression of human breast neoplasia. Am J Surg Pathol 2003, 27:1502-1512.

32. Prat A, Parker JS, Karginova O, Fan C, Livasy C, Herschkowitz Jl, He X, Perou CM: Phenotypic and molecular characterization of the claudin-low intrinsic subtype of breast cancer. Breast Cancer Res 2010, 12:R68.

33. Yang J, Weinberg RA: Epithelial-mesenchymal transition: at the crossroads of development and tumor metastasis. Dev Cell 2008, 14:818-829.

34. Peinado H, Portillo F, Cano A: Transcriptional regulation of cadherins during development and carcinogenesis. Int J Dev Biol 2004, 48:365-375.

35. Peinado H, Olmeda D, Cano A: Snail, Zeb and bHLH factors in tumour progression: an alliance against the epithelial phenotype? Nat Rev Cancer 2007, 7:415-428

36. Nielsen TO, Hsu FD, Jensen K, Cheang M, Karaca G, Hu Z, HernandezBoussard T, Livasy C, Cowan D, Dressler L, Akslen LA, Ragaz J, Gown AM Gilks CB, van de Rijn M, Perou CM: Immunohistochemical and clinical characterization of the basal-like subtype of invasive breast carcinoma. Clin Cancer Res 2004, 10:5367-5374.

37. Hirsch DS, Shen $Y$, Wu WJ: Growth and motility inhibition of breast cancer cells by epidermal growth factor receptor degradation is correlated with inactivation of Cdc42. Cancer Res 2006, 66:3523-3530.

38. Ramos JW: The regulation of extracellular signal-regulated kinase (ERK) in mammalian cells. Int I Biochem Cell Biol 2008, 40:2707-2719.

39. Levkowitz G, Waterman H, Ettenberg SA, Katz M, Tsygankov AY, Alroy I, Lavi S, Iwai K, Reiss Y, Ciechanover A, Lipkowitz S, Yarden Y: Ubiquitin ligase activity and tyrosine phosphorylation underlie suppression of growth factor signaling by c-Cbl/Sli-1. Mol Cell 1999, 4:1029-1040.

40. Pennock S, Wang Z: A tale of two Cbls: interplay of c-Cbl and Cbl-b in epidermal growth factor receptor downregulation. Mol Cell Biol 2008, 28:3020-3037.

41. Lee SL, Rouhi P, Dahl Jensen L, Zhang D, Ji H, Hauptmann G, Ingham P, Cao Y: Hypoxia-induced pathological angiogenesis mediates tumor cell dissemination, invasion, and metastasis in a zebrafish tumor model. Proc Natl Acad Sci USA 2009, 106:19485-19490.

42. Frosi Y, Anastasi S, Ballaro C, Varsano G, Castellani L, Maspero E, Polo S, Alema S, Segatto O: A two-tiered mechanism of EGFR inhibition by RALT/ MIG6 via kinase suppression and receptor degradation. J Cell Biol 2010, 189:557-571.

43. Samanta S, Sharma VM, Khan A, Mercurio AM: Regulation of IMP3 by EGFR signaling and repression by ERbeta: implications for triple-negative breast cancer. Oncogene 2012, 31:4689-4697.

44. Novelli F, Milella M, Melucci E, Di Benedetto A, Sperduti I, PerroneDonnorso R, Perracchio L, Venturo I, Nistico C, Fabi A, Buglioni S, Natali PG, Mottolese M: A divergent role for estrogen receptor-beta in nodepositive and node-negative breast cancer classified according to molecular subtypes: an observational prospective study. Breast Cancer Res 2008, 10:R74.

45. Shaaban AM, Green AR, Karthik S, Alizadeh Y, Hughes TA, Harkins L, Ellis IO, Robertson JF, Paish EC, Saunders PT, Groome NP, Speirs V: Nuclear and cytoplasmic expression of ERbeta1, ERbeta2, and ERbeta5 identifies distinct prognostic outcome for breast cancer patients. Clin Cancer Res 2008, 14:5228-5235.

doi:10.1186/bcr3358

Cite this article as: Thomas et al.: ERß1 represses basal-like breast cancer epithelial to mesenchymal transition by destabilizing EGFR. Breast Cancer Research 2012 14:R148. 